UDC $613 ; 614$

DOI: $10.21668 /$ health.risk/2021.2.15.eng

Review

\title{
ANALYTICAL REVIEW OF APPROACHES TO PROVIDING SAFETY WHEN SUBSTANTIATING HYGIENIC STANDARDS FOR CHEMICALS CONTENTS IN AMBIENT AIR
}

\author{
P.Z. Shur, A.A. Khasanova \\ Federal Scientific Center for Medical and Preventive Health Risk Management Technologies, 82 Monastyrskaya \\ Str., Perm, 614045, Russian Federation
}

A necessity to harmonize Russian sanitary-epidemiologic approaches with international standards is fixed in the federal legislation in the RF; given that, it seems vital to harmonize standards for ambient air quality taking into account a period of their averaging. To do that, previously methodical approaches were suggested to substantiating average annual MPC of chemicals in ambient air as per health risk criteria.

The research goal here was to make a review of previously applied and newly created methodical approaches to establishing average annual MPC taking into account an extent to which they were harmonized with international approaches and their capacity to provide safety for population.

As per results obtained via the performed literature review, we spotted out key elements in methodical approaches applied in the RF and abroad when substantiating standards for ambient air quality taking into account chronic inhalation exposure; the further analysis was performed in accordance with them.

It was detected that approaches applied to establish average annual MPC were partially harmonized since they didn't involve using threshold levels (BMC, BMCL); use of results obtained in previous studies to establish starting points in developing hygienic standards does not allow taking all the existing uncertainties into account. It seems impossible to estimate their safety as per health risk criteria due to absence of relevant parameters. Methodical approaches to substantiating average annual MPC as per health risk criteria are fully harmonized. Thus, they involve using BMC and BMCL for determining starting points when standards are being developed; values for such starting points can be established, among other things, as per data obtained via analyzing results of previous studies and are also supplemented when it comes down to taking uncertainty factors into account. Safety of developed average annual MPC is provided, among other things, due to obtained standards being verified as per acceptable (permissible) risk criteria. Given that, they can be used for developing harmonized average annual MPC.

Key words: average annual MPC, average daily MPC, hygienic standards, risk criteria, harmonization, ambient air, safety, methodical approaches.

The RF Government Order issued on standards" (last edited on September 04, September 28, 2009 No. 761 "On providing 2012) stipulates the necessity to modernize harmonization of Russian sanitary-epidemiologic requirements, veterinary-sanitary and phytosanitary measures with international regulatory and legal documents applied for control over ambient air quality ${ }^{1,2}[1]$. To do that, a domestic list of hygienic standards is

(C) Shur P.Z., Khasanova A.A., 2021

Pavel Z. Shur - Doctor of Medical Sciences, Academic Secretary, Senior researcher (e-mail: shur@fcrisk.ru; tel.: +7 (342) 238-33-37; ORCID: https://orcid.org/0000-0001-5171-3105).

Anna A. Khasanova - Researcher in the Health Risk Analysis Department (e-mail: KhasanovaAA@inbox.ru; tel.: +7 (342) 238-33-37; ORCID: https://orcid.org/0000-0001-7438-0358).

${ }^{1}$ On providing harmonization of Russian sanitary-epidemiologic requirements, veterinary-sanitary and phytosanitary measures with international standards: The RF Government Order issued on September 28, 2009 No. 761 (last edited on September 04, 2012). KonsultantPlus. Available at: http://www.consultant.ru/document/cons_doc_LAW 91969/(April 01, 2021).

${ }^{2}$ On approving the procedure for accomplishing examination of legal documents that stipulate sanitary-epidemiologic requirement in order to determine their conformity with international standards: The Order by the RF Ministry for Public Healthcare and Social Development issued on July 30, 2010 No. 581. KonsultantPlus. Available at: http://www.consultant.ru/document/cons_doc_LAW_104442/(March 25, 2021). 
being extended via including average annual maximum permissible concentrations $\left(\mathrm{MPC}_{\mathrm{av} . a n}\right)$ of chemicals in ambient air. This activity is essentially vital since in the RF only average daily maximum permissible concentrations $\left(\mathrm{MPC}_{\mathrm{av} . \mathrm{d} .}\right)$ were applied until recently for providing safety for population health under unlimited long-term exposure to chemicals $^{3}$. But in foreign countries average daily values are applied only to assess exposure to chemicals over 24 hours and are taken for a period not longer than 2 weeks; and average annual concentrations are usually applied to assess chronic exposure $[1,2]$. Thus, control over ambient air quality in foreign countries involves using, among other things, quality standards with values applied to assess risks of negative outcomes for health caused by chronic exposure to chemicals [3]. Such values include reference concentrations (RfCs) and minimal risk levels (MRL); chronic periods for such values correspond to those used for annual averaging $[4,5]$.

Public management in the sphere of providing sanitary-epidemiologic welfare for the country population is developing via updating public mechanisms that involves implementation of risk analysis elements. Given that, each element in the management system [6-8] should be added with a list of hygienic standards for ambient air quality that are averaged over a year $\left(\mathrm{MPC}_{\mathrm{av} . a n}\right)$ and are substantiated as per permissible (acceptable) health risks for population; it will allow using these standards as a criteria for assessing health risks under chronic inhalation exposure [9-11]. Adherence to these standards will allow providing safety (absence of impermissible risks for people's life and health) under chronic exposure to contaminants contained in ambient air.

Given the necessity to substantiate average annual hygienic standards as per risk cri- teria, it is advisable to develop harmonized methodical approaches based on existing domestic ones together with approaches applied for determining parameters that are used in risk assessment [12]. To do that, experts suggested certain methodical approaches to substantiating $\mathrm{MPC}_{\mathrm{av} . a n}$. for chemicals in ambient air as per health risk criteria [2]. They include an algorithm for fixing $\mathrm{MPC}_{\mathrm{av} . a n}$ that consists of some starting points (LOAEL, NOAEL, BMC, and BMCL, determined due to analyzing results obtained via previous research or as per experimental results); establishing relevant uncertainty factors (from 1 to 10 ); substantiating and validating all obtained standards as per permissible (acceptable) risks and assessing safety given life-long exposure to $\mathrm{MPC}_{\mathrm{av} . a n}$. These approaches can be used for establishing and substantiating harmonized $\mathrm{MPC}_{\mathrm{av} . a n}$. and it will allow using them as criteria for risk assessment under chronic inhalation exposure. To do that, we should assess methodical approaches to establishing $\mathrm{MPC}_{\mathrm{av} . d .}$ that were applied previously and newly developed approaches to establishing $\mathrm{MPC}_{\mathrm{av} . a n}$ taking into account an extent to which they are harmonized with international approaches and whether standards developed on their basis can truly provide safety for population.

Our research goal was to review domestic methodical approaches to substantiating standards for chemicals contents in ambient air under chronic exposure $\left(\mathrm{MPC}_{\mathrm{av} . d}\right.$. and $\mathrm{MPC}_{\mathrm{av} . a n .}$ ) taking into account an extent to which they were harmonized with international approaches and could provide safety for population.

To achieve this goal, we had to fulfill the following tasks:

1) to spot out key elements in domestic and foreign methodical approaches used for

\footnotetext{
${ }^{3}$ Temporary methodical guidelines on substantiating maximum permissible concentrations (MPC) of contaminants in ambient air in settlements. Moscow, USSR Public Healthcare Ministry; The Chief Sanitary-Epidemiologic Office / Approved by the USSR Public Healthcare Ministry on June 15, 1988, No. 4681-88, 1989, 110 p.
} 
establishing standards for chemicals contents in ambient air under chronic exposure $\left(\mathrm{MPC}_{\mathrm{av} . d .}\right.$ in the Russian Federation and average annual concentrations in foreign countries) basing on our review of scientific literature;

2) to assess an extent to which domestic approaches to establishing $\mathrm{MPC}_{\mathrm{av} . d \text {. for ad- }}$ verse chemicals in ambient air spotted out at the previous stage were harmonized with international ones and could provide safety for population;

3) to assess methodical approaches to substantiating $\mathrm{MPC}_{\mathrm{av} . \text { an. }}$ for chemicals in ambient air as per health risk criteria according to the obtained results taking into account an extent to which they were harmonized with international approaches and could provide safety for population.

Data and methods. To achieve our goal, we analyzed approaches applied in Russia and abroad for establishing ambient air quality standards. These approaches were determined basing on reviewing regulatory and methodical documents on the subject as well as previously performed surveys that were available in such databases as Research Gate, Scopus, Web of Science, Cyber Leninka, eLibrary, Google Scholar, NCBI PubMed, Elsevier.

Approaches applied for fixing $\mathrm{MPC}_{\mathrm{av} . d}$. for adverse chemicals in ambient air in the Russian Federation were stipulated in the Temporary methodical guidelines substantiating maximum permissible concentrations (MPC) of contaminants in ambient air in settlements No. 4681-88 issued on July 15, $1988^{3}$ and principles fixed within hygienic standardization paradigm. To analyze approaches to substantiating $\mathrm{MPC}_{\mathrm{av} \text {.an., we used }}$ methodical approaches to substantiating av- erage annual maximum permissible concentrations of adverse chemicals in ambient air in settlements as per permissible health risks [2]. To analyze worldwide experience in the sphere, we reviewed regulatory documents on ambient air quality issued by the US Environmental Protection Agency (USEPA), European Union (EU), US Agency for Toxic Substances and Disease Registry (ATSDR), and the World Health Organization (WHO) $[4,5]^{4,5,6}$.

Results and discussion. Basing on the review and analysis of data taken from available scientific literature, we spotted out the following key elements in domestic and foreign methodical approaches applied for establishing standards for chemicals contents under chronic exposure:

1) a period for averaging a standard;

2) use of safety criteria (absence of impermissible risk) when standards are substantiated;

3 ) use of results obtained via previously performed research for fixing initial parameters when developing new standards;

4) choice on exposure levels used as initial ones when hygienic standards are fixed;

5) a procedure for taking uncertainties into account.

$\mathrm{MPC}_{\mathrm{av} . d .}$ were used in the Russian Federation for a long period of time for assessing chronic effects produced by chemicals under unlimited long-term inhalation exposure. Average annual concentrations were established only for particulate matter $\mathrm{PM}_{10}$ and $\mathrm{PM}_{2.5}$ and tarry matter (peck sublime) in electrolysis dusts emitted from aluminum productions $^{7}$. But in world practice only average annual concentrations are used for providing safety under chronic inhalation exposure to chemicals in ambient air [2]

\footnotetext{
${ }^{4}$ Air Quality Guidelines for Europe. Second Edition. World Health Organization, Regional Office for Europe, Copenhagen, $2000,288 \mathrm{p}$.

${ }^{5}$ Technical Guidance Document on Risk Assessment. European Communities, 2003, 337 p.

${ }^{6}$ Guidelines for Human Exposure Assessment (EPA/100/B-19/001)// Risk Assessment Forum. Washington, DC, U.S. Environmental Protection Agency, 2019, 223 p.

${ }^{7}$ HS 2.1.6.3492-17. Maximum permissible concentrations (MPC) of contaminants in ambient air in urban and rural settlements. Available at: https://docs.cntd.ru/document/556185926 (April 03, 2021).
} 
since it provides greater safety for people during the whole life span. Given that, we can use them as criteria for health risk assessment which is an essential part of public management at every level at the contemporary stage in society development in Russia; health risk assessment is also considered a basic mechanism in developing policies aimed at reducing negative effects produced on population health in most countries and international organizations $[6-8,11,13,14]$. Use of this methodology is fixed in the RF sanitary legislation; however, it is limited due to absence of sufficient number of average annual standards and use of permissible risks for people's life or health as criteria that show safety of environmental factors [7].

Having reviewed all the available data and assessed an extent to which a period of time for averaging standards used in assessing chronic inhalation exposure to chemicals was harmonized with international approaches, we established that domestic approaches applied for establishing $\mathrm{MPC}_{\mathrm{av} . \mathrm{d}}$. were not harmonized with international ones. The reason is that only average annual concentrations are applied in world practice to assess chronic exposure to adverse chemicals [2].

The next key element was assessing an extent to which use of safety criteria (absence of impermissible risk) was harmonized in domestic and foreign practices when substantiating standards for chemicals contents in ambient air under chronic exposure.

The health risk assessment methodology used for assessing risks under exposure to chemicals that pollute the environment contains carcinogenic and non-carcinogenic risk criteria. HQ $\geq 1$ is fixed as permissible noncarcinogenic risk; permissible carcinogenic risks can be higher than $1 \cdot 10^{-6}$ but lower than $1 \cdot 10^{-4}$. This level is commonly used in most foreign hygienic standards and those recommended by international organizations when assessing risks for overall population (for example, the WHO stipulates $1 \cdot 10^{-4}$ as permissible risk for ambient air) ${ }^{8}$. Domestic methodology for establishing $\mathrm{MPC}_{\text {av.d. }}$ doesn't apply permissible risk criteria.

Having assessed harmonization, we established that this element was not harmonized due to the methodology for establishing $\mathrm{MPC}_{\text {av.d. not }}$ using criteria of permissible health risks; however, these criteria are used when most foreign standards are developed.

Having reviewed exposure levels used as initial ones for establishing hygienic standards, we revealed that foreign practices mostly relied on NOAEL (non-effective level), LOAEL (lowest observed effect level), BMC (benchmark concentration) and BMCL (lower limit of BMC CI $)^{4,5,9}$ [15-17].

It is assumed that there is a concentration for most chemicals that produce toxic effects below which no side effects can be observed (that is, a threshold); such a concentration can be taken as a threshold one in the first approximation. NOAEL is a value often used for assessing exposure threshold. In an experiment NOAEL is determined as the highest experimentally detected exposure level that does not cause statistically or biologically significant increase in frequency or gravity of side effects ${ }^{9}$. In case NOAEL can't be estimated, LOAEL is used in assessment with extrapolation onto NOAEL via using a modifying factor $[15,17]$. In an experiment, LOAEL is the lowest dose that can produce unfavorable effects. Use of NOAEL has certain limitations [16, 18-20]. Thus, NOAEL is essentially an experimental dose and takes into account changeability in determining its statistical significance against a reference group. Given that, we can't exclude unfavorable effects occurring under exposure to NOAEL as per statistical

\footnotetext{
${ }^{8}$ The Guide on assessing health risks for population under exposure to chemicals that pollute the environment. Moscow, The Federal Center for State Sanitary Epidemiologic Surveillance of the RF Public Healthcare Ministry, 2004, $143 \mathrm{p}$

${ }^{9}$ Guidelines for Exposure Assessment (EPA/600/Z-92/001). Risk Assessment Forum. Washington, DC, U.S. Environmental Protection Agency, 1992, 139 p.
} 
and analytical reasons. Besides, NOAEL value is influenced by a sampling size since a response to a certain concentrations is compared with a response given by a reference group [21]. Given that, an opportunity to observe statistical difference will decrease as a number of animals under exposure goes down and, consequently, there will be a growth in NOAEL [20]. Therefore, NOAEL value depends on a number of experimental concentrations and an interval between them [22]. These and some other limitations of this approach encouraged searching for alternatives; a procedure that applies a benchmark concentration (BMC) has become one of them. BMC is a statistical lower confidence limit of exposure that causes an established negative effect [16, 23-26]. BMC can be used both in experiments on animals and for establishing reference health parameters basing on epidemiological data ${ }^{10}[27,28]$. BMCL is the lower limit of PMC CI that is determined as a point on a curve showing "dose - response" dependence; this point is usually determined basing on experimental data and usually corresponds to low exposure level (from 1 to $10 \%$ ). Abroad BMC is applied by USEPA for determining reference concentrations $^{5}$ [18]. This approach that applies benchmark doses is also used as an alternative for the traditional NOAEL-based one within OECD activities and when technical regulatory principles are revised in the EU for new and existing chemicals [29].

When standards are being developed and there are data on several starting points, it is advisable to select such parameters that require applying as few uncertainty factors as it is only possible. And use of BMC and BMCL seems to be the most optimal in this respect since these parameters are developed basing on mathematical modeling of "dose - response" dependence and using available relevant data obtained via other experiments [25-28].
Hygienic standardization in Russia applies several initial parameters for establishing $\mathrm{MPC}_{\mathrm{av} . d \text {.; }}$ they are threshold and maximum non-effective concentrations similar to NOAEL (no effect level) and LOAEL (lowest observed effect level) that are applied $\operatorname{abroad}^{4}[30,31]$. But we should mention that reference parameters, such as BMC and BMCL, are not applied in Russia though they are quite widely used by international organizations. Therefore, the performed review allowed establishing that domestic approaches used for determining $\mathrm{MPC}_{\mathrm{av} . d \text {. were }}$ partially harmonized regarding applied exposure levels.

Use of results obtained via previously performed research for establishing initial parameters when standards were developed was analyzed as the next key element. This approach is widely used in international practice due to its capability to provide wide opportunities for using data on effects produced by toxicants on health accumulated both in foreign and domestic literature. These data have been obtained via previous toxicological and epidemiologic research and it allows avoiding duplication of results and to a certain extent makes the process less labor-consuming and expensive. This stage involves analyzing all the available data on results obtained via previously performed research on negative effects produced by a chemical in order to assess their sufficiency for establishing initial parameters required for developing a certain standard [2]. To do that, a database is created that covers all previously performed research works on negative effects produced by an examined chemical that correspond to relevance criteria. Such databases use conventional information sources such as domestic and international databases (including Scopus, Web of Science, CyberLeninka, eLibrary, Google Scholar, NCBI PubMed, Elsevier, Research

\footnotetext{
${ }^{10}$ Benchmark Dose Technical Guidance (EPA/100/R-12/001). Risk Assessment Forum. Washington, DC, U.S. Environmental Protection Agency, 2012, 99 p.
} 
Gate) and reviewed scientific editions. Then, it is necessary to qualitatively assess this created database; basing on its results key research papers are selected and they are estimated in accordance with minimal criteria for database completeness. In case they correspond to these criteria, qualitative and integral assessment of selected research papers is performed in order to estimate whether there are enough data for establishing initial parameters required to substantiate a hygienic standard. In case data are sufficient, then a standard is fixed as per results obtained via previous research. Should data be insufficient, then conventional experimental toxicological and/or epidemiologic research is required or new data should be analyzed again after some new research papers have been published. Within these approaches it is also possible to revise all obtained values when new experimental data have been published after accomplished experiments that concentrated on effects produced by an examined chemical; these new data can be used in developing and substantiating new hygienic standards.

When $\mathrm{MPC}_{\mathrm{av} . d .}$ are determined in Russia, literature data are analyzed for characterizing physical-chemical and toxicological properties of a standardized chemical. And initial parameters that are used as grounds for establishing a standard are determined only as per results obtained via performed experimental research.

Having assessed to what extent this element in Russia was harmonized with international practices we established that harmonization was only partial since the procedure

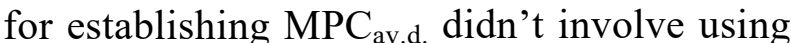
results obtained via previous research when a new standard was established; however, they are applied when a chemical is described at a stage that involves creating an experiment design.

Having reviewed domestic and foreign regulatory and methodical documents, we concluded that standards for chemicals con- tents in ambient air under chronic exposure were fixed basing on starting points with their adjustment as per uncertainty factors in foreign practices regarding ambient air quality standards and with assurance factors in domestic hygienic standardization, including $\mathrm{MPC}_{\text {av.d. }}$ establishment [4, 5, 32-34].

Assurance factor is determined depending on an overall idea of a hazard caused by a chemical both as per toxicometric parameters and qualitative parameters of effects it produces; variability of species sensitivity; conditions and factors that influence precision of threshold values substantiated during an experiment, a coefficient used for extrapolating data obtained via using a limited number of experimental animals onto human population $^{3}$. That is, they take into account, how many times $\mathrm{MPC}_{\mathrm{av} . d \text {. for a specific chemical }}$ that is established for people is less than a chronic exposure threshold determined in experiments on animals.

International organizations and EU countries apply uncertainty factors (UF) when developing ambient air quality standards and taking uncertainties into account. These uncertainty factors have been developed for most spheres where uncertainties may occur [35, 36]. Thus, there are factors that take into account intra-species uncertainty (the most sensitive groups), interspecies uncertainty (when results obtained via laboratory experiments on animals are extrapolated on people), extrapolation of data obtained in acute, sub-chronic and chronic examinations for the whole life span, using threshold levels instead of noneffective ones, using incomplete data arrays $^{4,6}[32,34,37,38]$. Therefore, an approach that involves using UF allows taking more uncertainties into account than an approach based on applying assurance factors; the formed allows developing standards that correspond to lower exposure levels than those that, according to available data, may cause negative outcomes for health among the most sensitive population groups. 
Recommendations on harmonizing domestic methodical approaches to establishing $M P C_{\text {av.d. }}$ for chemicals contents in ambient air

\begin{tabular}{|c|c|c|c|}
\hline \multirow[b]{2}{*}{ Harmonization point } & \multicolumn{2}{|c|}{ Current situation } & \multirow{2}{*}{$\begin{array}{c}\text { Recommendations } \\
\text { on domestic approaches } \\
\text { harmonization }\end{array}$} \\
\hline & The Russian Federation & \begin{tabular}{c|} 
Foreign countries and \\
international organizations
\end{tabular} & \\
\hline $\begin{array}{l}\text { 1. Standards averaging under } \\
\text { chronic inhalation exposure }\end{array}$ & $\begin{array}{l}\text { Basically } \mathrm{MPC}_{\mathrm{av.d.}} \text { and } \\
\text { several } \mathrm{MPC}_{\mathrm{av} . \mathrm{an}}\end{array}$ & $\begin{array}{l}\text { Standards are average only for } \\
\text { a year }\end{array}$ & $\begin{array}{l}\text { To add a list of domestic stan- } \\
\text { dards with } \mathrm{MPC}_{\mathrm{av} . \mathrm{an}}\end{array}$ \\
\hline $\begin{array}{l}\text { 2. Use of safety criterion (no } \\
\text { impermissible risk) when } \\
\text { substantiating standards }\end{array}$ & Are not used & $\begin{array}{l}\text { Permissible risk criteria are } \\
\text { widely used }\end{array}$ & $\begin{array}{l}\text { To provide for using permissi- } \\
\text { ble risk criteria when substanti- } \\
\text { ating standards }\end{array}$ \\
\hline $\begin{array}{l}\text { 3. Selecting levels of expo- } \\
\text { sure used as initial ones for } \\
\text { establishing hygienic stan- } \\
\text { dards }\end{array}$ & $\begin{array}{l}\text { Minimal effective con- } \\
\text { centrations and maximum } \\
\text { non-effective concentra- } \\
\text { tion }\end{array}$ & $\begin{array}{l}\text { LOAEL (lowest observed ef- } \\
\text { fect level), NOAEL (maximum } \\
\text { non-effective level), BMC, } \\
\text { BMCL (threshold levels) }\end{array}$ & $\begin{array}{l}\text { To develop a procedure for } \\
\text { using NOAEL, LOAEL, BMC, } \\
\text { BMCL when establishing hy- } \\
\text { gienic standards }\end{array}$ \\
\hline $\begin{array}{l}\text { 4. Use of results obtained via } \\
\text { previous research for estab- } \\
\text { lishing initial parameters } \\
\text { when standards are devel- } \\
\text { oped }\end{array}$ & \begin{tabular}{|l|} 
Previously accomplished \\
research works are used \\
only to characterize a \\
chemical and starting \\
points are established as \\
per experimental research \\
results исследований
\end{tabular} & $\begin{array}{l}\text { Starting points can be estab- } \\
\text { lishing via analyzing results } \\
\text { obtained via previous research } \\
\text { and no experiments are re- } \\
\text { quired in case they are suffi- } \\
\text { cient }\end{array}$ & $\begin{array}{l}\text { To develop methodical ap- } \\
\text { proaches to substantiating } \\
\text { standards basing on results } \\
\text { obtained via previous research }\end{array}$ \\
\hline $\begin{array}{l}\text { 5. A procedure for taking } \\
\text { uncertainties into account }\end{array}$ & Assurance factors & $\begin{array}{l}\text { Uncertainty factors (allow tak- } \\
\text { ing a wider range of uncertain- } \\
\text { ties into account) }\end{array}$ & $\begin{array}{l}\text { To modify a domestic system } \\
\text { for taking uncertainties into } \\
\text { account when developing stan- } \\
\text { dards via including additional } \\
\text { spheres }\end{array}$ \\
\hline
\end{tabular}

Basing on the performed review, we established that this element was partially harmonized since the procedure for estab-

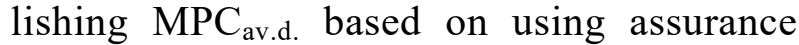
factors didn't allow taking into account the whole range of uncertainties that occurred when standards were developed.

To sum up, we reviewed domestic methodical approaches to establishing $\mathrm{MPC}_{\mathrm{av} . d}$. and assessed to what extent they were harmonized with international ones; it allowed us to reveal that all domestic approaches were partially harmonized since they didn't involve using criteria of permissible health risks, threshold levels (BMC, BMCL) and uncertainty factors as well as using results obtained via previous research to substantiate standards. It seems impossible to assess safety (absence of impermissible risk) of $\mathrm{MPC}_{\mathrm{av} . d}$. determined within existing approaches due to parameters necessary for such assessment being unavailable.

Basing on the obtained results, we developed some recommendations that would allow providing full harmonization of domestic approaches with international ones as per the examined key elements (Table).

According to developed recommendations we assessed methodical approaches to substantiating $\mathrm{MPC}_{\mathrm{av} . \text { an. for chemicals in }}$ ambient air as per health risk criteria and taking into account to what extent they were harmonized with international ones and provided safety for population. We revealed that these domestic approaches were completely harmonized with international ones since they involved establishing $\mathrm{MPC}_{\mathrm{av} . \mathrm{an}}$. and permissible risk criteria when they were substantiated for assessing chronic inhalation exposure to chemicals. A procedure for using NOAEL, LOAEL, BMC, and BMCL for fixing hygienic standards is developed within these approaches; these values can be determined, among other things, as per analyzing results obtained via previous research. An extended list of spheres is applied for taking uncertainties into account; this list is supplemented with relevant data on obtain- 
ing more precise values in harmonized ranges. When it comes to safety assessment, average annual standards developed according to these methodical approaches provide absence of impermissible risk due to permissible risk criteria being used in their development; obtained $\mathrm{MPC}_{\mathrm{av} . \text { an. }}$ are also verified via applying evolution models for calculating whether health risk under life-long exposure conforms to permissible levels. All this

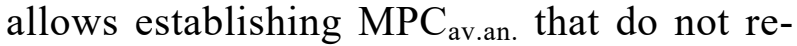
sult in impermissible life-long health risks for population including the most sensitive groups.

Harmonized methodical approaches to substantiating $\mathrm{MPC}_{\mathrm{av} . a n}$. for chemicals in ambient air as per health risk criteria were used within the Sanitary-Epidemiologic Rules 1.2.3685-21 "Hygienic standards for providing safety and (or) harmlessness of environmental factors for people" ${ }^{\prime 1}$. However, some values there do not coincide numerically with reference concentrations (RfC) fixed in "The Guide on assessing health risks for population under exposure to chemicals that pollute the environment"12 which is a fundamental document applied in risk assessment procedures. It is due to effects produced by so called principle of renewal when previously established values are revised after new data have been obtained that are relevant for establishing and substantiating them. Thus, $\mathrm{MPC}_{\mathrm{av} . \text { an. }}$ for mercury was fixed two orders lower than RfC since in 2008 OENNA approved a new, lower LOAEL value for effects produced by this element on the nervous system [39]; differences in values obtained for ethylbenzene are caused by new LOAEL approved for this element by ATSDR in 2010 and lower MLR was offered basing on it [40]; LOAEL for ethenylbenzene (styrene) were renewed by
ATSDR in 2012 and it also led to difference in standards developed on this basis [41]. Differences in $\mathrm{MPC}_{\mathrm{av} . \text { an. }}$ established for such chemicals as tetrachrolomethane, chloroethane, and vinyl chloride are detected due to $\mathrm{RfC}$ values being fixed only as per noncarcinogenic risk criteria whereas $M P C_{a v . a n .}$ were calculated as per both non-carcinogenic and carcinogenic risks criteria. It provides greater safety under chronic exposure to these chemicals. Given all the above mentioned, differences in numeric values were caused by new data becoming available and it allowed calculating new values.

Therefore, methodical approaches to substantiating $\mathrm{MPC}_{\mathrm{av} . a n}$. for chemicals in ambient air as per health risk criteria are fully harmonized with international ones and allow establishing $\mathrm{MPC}_{\mathrm{av} . a n}$ that cannot cause unacceptable life-long health risks for population including the most sensitive groups.

Conclusion. Our analytical review of data available in scientific literature allowed us to spot out key elements in domestic and foreign methodical approaches applied for establishing standards for chemicals contents in ambient air under chronic exposure. These key elements included a period for a standard averaging, choice on starting points, use of results obtained via previous research for establishing initial parameters when developing standards, a procedure for taking uncertainties into account, and use of safety criterion (absence of impermissible risk). We revealed that approaches applied for developing $\mathrm{MPC}_{\mathrm{av} . d \text {. were only partially harmo- }}$ nized since they didn't involve using threshold levels (BMC, BMCL) and results obtained via previous research for establishing starting points when hygienic standards were developed; they also didn't allow taking into account the whole range of uncertainties that

\footnotetext{
${ }^{11}$ SER 1.2.3685-21. Hygienic standards for providing safety and (or) harmlessness of environmental factors for people. KODEKS: an electronic fund for legal and reference documentation. Available at: https://docs.cntd.ru/document/573500115 (April 03, 2021).

${ }^{12}$ The Guide on assessing health risks for population under exposure to chemicals that pollute the environment. Moscow, The Federal Center for State Sanitary Epidemiologic Surveillance of the RF Public Healthcare Ministry, 2004, 143 p.
} 
occurred when a standard was developed. It doesn't seem possible to assess safety of average daily standards as per health risk criteria due to parameters necessary for risk assessment being not available for them. Basing on the obtained results, we developed some recommendations that would allow full harmonization of domestic approaches with world practices; these recommendations were taken into account within methodical approaches to substantiating $\mathrm{MPC}_{\mathrm{av} \text {.an. for }}$ chemicals in ambient air as per health risk criteria. These approaches are fully harmonized since they involve fixing $\mathrm{MPC}_{\mathrm{av} \text {.an. for }}$ assessing impacts exerted by chronic exposure to adverse chemicals; they suggest a procedure for using NOAEL, LOAEL, BMC, BMCL for establishing starting points when standards are developed and these values can be established, among other things, basing on data obtained via previous research; these approaches are also supplemented with new instruments regarding uncertainty factors. Safety of $\mathrm{MPC}_{\mathrm{av} . a n}$. values developed within these approaches is provided, among other things, due to using permissible risk criteria in their development. It allows developing average annual standards that do not cause unacceptable life-long health risks for population, including the most sensitive groups. Methodical approaches to substantiating $\mathrm{MPC}_{\mathrm{av} . a n}$. for chemicals in ambient air as per health risk criteria are fully harmonized with international ones and can be used for establishing harmonized $\mathrm{MPC}_{\mathrm{av} . a n}$.

Funding. The research was not granted any sponsor support.

Conflict of interests. The authors declare there is no any conflict of interests.

\section{References}

1. Avaliani S.L., Novikov S.M., Shashina T.A., Skvortsova N.S., Kislitsin V.A., Mishina A.L. Problems and ways of solutions to harmonize standards for air pollution. Gigiena i sanitariya, 2012, vol. 91, no. 5, pp. 75-78 (in Russian).

2. Zaitseva N.V., Shur P.Z., Chetverkina K.V., Khasanova A.A. Developing methodical approaches to substantiating average annual maximum permissible concentrations of hazardous substances in ambient air in settlements as per acceptable health risk. Health Risk Analysis, 2020, no. 3, pp. 39-48. DOI: 10.21668/health.risk/2020.3.05.eng

3. Sinitsyna O.O., Zholdakova Z.I., Kharchevnikova N.V. Nauchnye osnovy edinogo ekologogigienicheskogo normirovaniya khimicheskikh veshchestv $\mathrm{v}$ okruzhayushchei srede [Scientific grounds for unified ecological-hygienic standardization of chemicals in the environment]. Itogi $i$ perspektivy nauchnykh issledovanii po problem ekologii cheloveka i gigieny okruzhayushchei sredy. In: Yu.A. Rakhmanin ed. Moscow, Nauchno-issledovatel'skii institute ekologii cheloveka i gigieny okruzhayushchei sredy im. A.N. Sysina Publ., 2001, pp. 106-123 (in Russian).

4. A Review of the Reference Dose and Reference Concentration Processes. Reference Dose/Reference Concentration (RfD/RfC) Technical Panel. Final report (EPA/630/P-02/002F). Risk Assessment Forum. Washington, DC, U.S.EPA, 2002, 192 p.

5. Minimal Risk Levels (MRLs). The Agency for Toxic Substances and Disease Registry. Available at: https://www.atsdr.cdc.gov/minimalrisklevels/ (15.03.2021).

6. Zaitseva N.V., Popova A.Yu., May I.V., Shur P.Z. Methods and technologies of health risk analysis in the system of state management under assurance of the sanitation and epidemiological welfare of population. Gigiena i sanitariya, 2015, vol. 94, no. 2, pp. 93-98 (in Russian).

7. Zaitseva N.V., Popova A.Yu., Onishchenko G.G., May I.V. Current problems of regulatory and scientific-medical support for the assurance of the sanitary and epidemiological welfare of population in the Russian Federation as the strategic government task. Gigiena i sanitariya, 2016, vol. 95, no. 1, pp. 5-9 (in Russian).

8. Gurvich V.B., Kuz'min S.V., Dikonskaya O.V., Gileva M.A., Boyarskii A.P. Methodical approaches, experience and perspectives of the implementation of the risk model of surveillance activi- 
ties in the sphere of the assurance of sanitary and epidemiological welfare of population, population's health risk management and the consumer rights protection. Gigiena i sanitariya, 2015, vol. 94, no. 2, pp. 104-108 (in Russian).

9. Rakitskii V.N., Avaliani S.L., Shashina T.A., Dodina N.S. Actual problems of population health risks management in Russia. Gigiena i sanitariya, 2018, vol. 97, no. 6, pp. 572-575 (in Russian).

10. Rakhmanin Yu.A. Actualization of methodological problems of reglamentation of chemical pollutions on the environment. Gigiena i sanitariya, 2016, vol. 95, no. 8, pp. 701-707 (in Russian).

11. Popova A.Yu., Gurvich V.B., Kuz'min S.V., Orlov M.S. The paradigm of the development of the regulatory and methodological framework aimed to maintain sanitary and epidemiological welfare of the population. Gigiena i sanitariya, 2017, vol. 96, no. 12, pp. 1226-1230 (in Russian).

12. Avaliani S.L., Mishina A.L. Harmonization of approaches to management of air quality. Zdorov'e naseleniya i sreda obitaniya, 2011, vol. 216, no. 3, pp. 44-48 (in Russian).

13. Zaitseva N.V., Tutel'yan V.A., Shur P.Z., Khotimchenko S.A., Sheveleva S.A. Experience of justification of hygienic standards of food safety with the use of criteria for the risk for population health. Gigiena i sanitariya, 2014, vol. 93, no. 5, pp. 70-74 (in Russian).

14. Andreeva E.E., Ivanenko A.V., Siliverstov V.A., Sudakova E.V. Application of methodology for the assessment of risk for public health from harmful environmental factors in the practice activity of the office of service for supervision of consumer rights protection and human welfare in the city of Moscow. Gigiena i sanitariya, 2016, vol. 95, no. 2, pp. 219-222 (in Russian).

15. Gaylor D., Kodell R. A procedure for developing risk-based reference doses. Regul. Toxicol. Pharmacol, 2002, vol. 35, no. 2, pp. 137-141. DOI: 10.1006/rtph.2002.1533

16. Travis K.Z., Pate I., Welsh Z.K. The role of the benchmark dose in a regulatory context. Regul. Toxicol. Pharmacol, 2005, vol. 43, no. 3, pp. 280-291. DOI: 10.1016/j.yrtph.2005.07.003

17. Gaylor D., Ryan L., Krewski D., Zhu Y. Procedures for calculating benchmark doses for health risk assessment. Regul. Toxicol. Pharmacol, 1998, vol. 28, no. 2, pp. 150-164. DOI:10.1006/rtph.1998.1247

18. Filipsson A., Sand S., Nilsson J., Victorin K. The benchmark dose method-review of available models, and recommendations for application in health risk assessment. Crit. Rev. Toxicol, 2003, vol. 33, no. 5, pp. 505-542.

19. Dorato M.A., Engelhardt J.A. The no-observed-adverse-effect-level in drug safety evaluations: use, issues, and definition(s). Regul. Toxicol. Pharmacol, 2005, vol. 42, no. 3, pp. 265-274. DOI: $10.1016 /$ j.yrtph.2005.05.004

20. Faustman E., Bartell S. Review of Noncancer Risk Assessment: Application of the Benchmark Dose Methods. Human and Ecological Risk Assessment, 1997, vol. 3, no. 5, pp. 893-920. DOI: $10.1080 / 10807039709383733$

21. Herrman J.L., Younes M. Background to the ADI/TDI/PTWI. Regul. Toxicol. Pharmacol, 1999, vol. 30, no. 2, pp. 109-113. DOI: 10.1006/rtph.1999.1335

22. Speijers G.J. Precision of estimates of an ADI (or TDI or PTWI). Regul. Toxicol. Pharmacol, 1999, vol. 30, no. 2, pp. 87-93. DOI: 10.1006/rtph.1999.1331

23. Wignall J.A., Shapiro A.J., Wright F.A., Woodruff T.J., Chiu W.A., Guyton K.Z., Rusyn I. Standardizing benchmark dose calculations to improve science-based decisions in human health assessments. Environ. Health Perspect, 2014, vol. 122, no. 5, pp. 499-505. DOI:10.1289/ehp.1307539

24. Sand S., Rosen D., Victorin K., Filipsson A.F. Identification of a critical dose level for risk assessment: developments in benchmark dose analysis of continuous endpoints. Toxicol. Sci, 2006, vol. 90, no. 1, pp. 241-251. DOI:10.1093/toxsci/kfj057

25. Edler L., Kopp-Schneider A. Statistical models for low dose exposure. Mutat. Res, 1998, vol. 405, no. 2, pp. 227-236. DOI: 10.1016/s0027-5107(98)00140-7

26. Crump K. Calculation of the benchmark doses from continuous data. Risk Anal, 1995, vol. 15, no. 1, pp. 79-89. DOI: 10.1111/j.1539-6924.1995.tb00095.x

27. Crump K. Critical issues in benchmark calculations from continuous data. Crit. Rev. Toxicol, 2002, vol. 32, no. 3, pp. 133-153. DOI: 10.1080/20024091064200

28. Budtz-Jorgensen E. Benchmark dose calculations from epidemiological data. Biometrics, 2001, vol. 57, no. 3, pp. 698-706. DOI: 10.1111/j.0006-341x.2001.00698.x 
29. Krewski D., Zhu Y., Fung K. Benchmark doses for developmental toxicants. Inhalation Toxicology, 1999, vol. 11, no. 6-7, pp. 579-591. DOI: 10.1080/089583799196998

30. Barlow S.M., Greig J.B., Bridges J.W., Carere A., Carpy A.J.M., Galli C.L., Kleiner J., Knudsen I. [et.al.]. Hazard identification by methods of animal-based toxicology. Food Chem. Toxicol, 2002, vol. 40, no. 2-3, pp. 145-191. DOI: 10.1016/s0278-6915(01)00117-x

31. McClellan R.O. Human health risk assessment: A historical overview and alternative paths forward. Inhal. Toxicol, 1999, vol. 11, no. 6-7, pp. 477-518. DOI: 10.1080/089583799196880

32. Methods for Derivation of Inhalation Reference Concentrations and Application of Inhalation Dosimetry (EPA/600/8-90/066F). Office of Research and Development. USA, U.S. Environmental Protection Agency, Research Triangle Park, NC, 1994, 289 p.

33. Review of EPA's Integrated Risk Information System (IRIS) Process. Washington, DC, The National Academies Press Publ., 2014, 170 p.

34. Chemical-specific adjustment factors for interspecies differences and human variability: guidance document for use of data in dose/concentration-response assessment. World Health Organization, International Programme on Chemical Safety (IPCS). Harmonization Project Document, no. $2,100 \mathrm{p}$.

35. Khasanova A.A. Analiz otechestvennykh i zarubezhnykh metodicheskikh podkhodov $\mathrm{k}$ uchetu neopredelennostei pri ustanovlenii gigienicheskikh normativov soderzhaniya vrednykh veshchestv $\mathrm{v}$ atmosfernom vozdukhe [Analysis of domestic and foreign methodical approaches to taking uncertainties into account when developing hygienic standards for adverse chemicals contents in ambient air]. Analiz riska zdorov'yu - 2020 sovmestno s mezhdunarodnoi vstrechei po okruzhayushchei srede i zdorov'yu RISE-2020 i kruglym stolom po bezopasnosti pitaniya: Materialy X Vserossiiskoi nauchno-prakticheskoi konferentsii s mezhdunarodnym uchastiem. In: A.Yu. Popova, N.V. Zaitseva eds. Perm', Izdatel'stvo Permskogo natsional'nogo issledovatel'skogo politekhnicheskogo universiteta Publ., 2020, vol. 1, pp. 100-107 (in Russian).

36. Sussman R.G., Naumann B.D., Pfister T., Sehner C., Seaman C., Weideman P.A. A harmonization effort for acceptable daily exposure derivation - Considerations for application of adjustment factors. Regul. Toxicol. Pharmacol, 2016, vol. 79, no. 1, pp. 57-66. DOI: 10.1016/j.yrtph.2016.05.023

37. Uncertainty factors: Their use in human health risk assessment by UK Government. The Interdepartmental Group on Health Risks from Chemicals. Institute for Environment and Health, 2003, $73 \mathrm{p}$.

38. Exposure Factors Handbook 2011 Edition (Final Report) (EPA/600/R-09/052F). Washington, DC, U.S. Environmental Protection Agency, 2011, 1436 p.

39. OEHHA Acute, 8-hour and Chronic Reference Exposure Level (REL). The Office of Environmental Health Hazard Assessment. Available at: https://oehha.ca.gov/ (20.05.2021).

40. Toxicological profile for ethylbenzene. U.S. Department of health and human services Public Health Service, Agency for Toxic Substances and Disease Registry, 2010, 341 p.

41. Toxicological profile for styrene. U.S. Department of health and human services Public Health Service, Agency for Toxic Substances and Disease Registry, 2010, 283 p.

Shur P.Z., Khasanova A.A. Analytical review of approaches to providing safety when substantiating hygienic standards for chemicals contents in ambient air. Health Risk Analysis, 2021, no. 2, pp. 154-164. DOI: 10.21668/health.risk/2021.2.15.eng

Received: 08.04.2021

Accepted: 16.06 .2021

Published: 30.09 .2021 